\title{
Commerce in health services in North America within the context of the North American Free Trade Agreement ${ }^{1}$
}

\author{
Octavio Gómez-Dantés, ${ }^{2}$ Julio Frenk, ${ }^{3}$ and Carlos Cruz $^{4}$
}

ABSTRACT This article discusses the future of commercial trade in personal health services in North America within the context of the North American Free Trade Agreement (NAFTA) and the latter's potential influence on health care for the Mexican people. It begins by defining concepts related to international trade of services, particularly health services, and then proceeds to analyze elements of NAFTA that affect the delivery, regulation, and financing of such services, as well as their future trade within the NAFTA area. It concludes with some recommendations directed at helping Mexico's national health care system confront the risks posed while taking advantage of the opportunities offered by the Mexican economy's entry into a broader market.

International trade is an economic activity that benefits most countries for three fundamental reasons. In the first place, the diverse conditions of production found in different regions allow each country to concentrate on producing those goods or services for which it is best suited in terms of natural resources, labor, capital, or technology. Second, production costs are

1 Published in Spanish in the Boletin de la Oficina Sanitaria Panamericana, 1996, Vol. 120, No. 4, pp. 282-290, with the title "El comercio de servicios de salud en América del Norte en el contexto del Tratado de Libre Comercio."

2 Ministry of Health, General Directorate for Evaluation and Followup, Mexico City, Mexico. Mailing address: Reina 92, Colonia San Ángel, 01000 México, DF, México. Telephone and facsimile: 550 8672.

3 Mexican Foundation for Health, Mexico City, Mexico.

4 Ministry of Health, Mexico City, Mexico. reduced, and it is possible to achieve what are known as economies of scale. Finally, international trade provides access to products that satisfy a wide variety of tastes (1). However, these factors that support international trade arise from a more profound underlying principle: the principle of comparative advantage, according to which each country will tend to specialize in the production and export of those goods and services that it can produce at a relatively low cost and, similarly, to import those goods and services that it produces at a relatively high cost.

For this and other reasons, recent years have witnessed a strengthening in the trend toward creating international trade blocs. Free trade areas allow complementary activities to take place within their borders that rein- force the comparative advantages of the countries involved. And while they give the initial impression of discriminating against excluded countries, over time preferential trade agreements lead to an extraordinary economic dynamism that benefits even those economies not participating directly in them (2).

One such trade agreement is the North American Free Trade Agreement (NAFTA), which went into effect in January 1994. The purpose of this article is to discuss the future prospects of the trade in personal health services in North America within the context of NAFTA and the possible influence of the latter on health care available to the Mexican people. The first part defines the concepts underlying the international trade in services, with emphasis on 
health services. The second analyzes those sections of NAFTA related directly to the provision, regulation, and financing of health services and discusses the future trade in this type of services within the area encompassed by the treaty. This in turn leads into a number of concluding recommendations for strengthening the Mexican national health system in such a way as to enable it to address the risks and take advantage of the opportunities accruing from the Mexican economy's entry into a broader market.

\section{TRADE IN HEALTH SERVICES IN NORTH AMERICA}

No one with sound judgment should harbor any doubts about the increasing importance of the service sector in the modern world. In developing countries, this sector accounts for almost $60 \%$ of the gross domestic product, while in moderate- to lowincome countries it already accounts for more than 50\% (3). North America is no exception. In Canada, the United States, and Mexico the service sector accounts for some $65 \%$ of total production and over $60 \%$ of total employment (4). With regard to Mexico alone, $61.5 \%$ of total production and $51.2 \%$ of the economically active population were concentrated in the tertiary or service sector in 1993 (5). The importance of this sector is also reflected in international trade. Between 1970 and 1991 the international trade in services grew at an average annual rate of $11.5 \%$, totaling over US\$ 1 trillion by the beginning of the 1990s (6).

Even more important than the quantitative growth of services is their qualitative development. Since the mid-1970s, developed countries have been experiencing a "service revolution"; productive tasks have become increasingly dependent on processes and decreasingly dependent on raw materials, while so-called "soft" or process technologies have begun to displace "hard" or product technolo- gies (7). The new technologies are information-, knowledge-, and organization-intensive, and are being generated or distributed primarily in the service sector.

\section{TRADE OF SERVICES}

Economists define services as intangible goods (8) or as that component of the gross national product that accounts for the total production of such goods (9). For statistical specialists whose job it is to calculate national income, the balance of payments, and the relationship between them, the export of services is defined as the sale of intangible goods to individuals or firms in other countries, while their import is defined as the buying of such goods from individuals or firms abroad (10). Accordingly, the international trade of services may be defined as the buying and selling of intangible goods by individuals or firms in different countries.

In general, the international trade in services must meet two conditions: There must be movement across a border of the service and appropriate payment, and the movement must be of limited duration (11). Given these two conditions, it is possible to identify three basic forms of international trade in services: 1) pure movement across a border, whether by electronic communication, satellite, regular mail, or other means of transport; 2) the movement across a border of the consumer to procure service in the producing country; and 3) the movement across a border of some of the factors of production (such as labor or capital) to generate the service in another country.

Of course, international transactions in the tertiary sector, as in practically all sectors, may be subject to a wide variety of restrictions. Some of these take the same form as those applied to commodities: tariffs, licenses, and import quotas, or even government subsidies and discriminatory policies. Others constrain trade of services by imposing limits on investment oppor- tunities. (The purpose in the latter case is to increase government revenues while favoring development of certain sectors of the national economy.) Finally, there may be absolute barriers (prohibiting all foreign participation in a market) or partial barriers (limiting the activities of foreign firms by imposing discriminatory requirements on their operations in order to promote the competitiveness of national firms).

\section{INTERNATIONAL TRADE OF HEALTH SERVICES}

Health care services cannot be studied in isolation. That is because they relate closely to a broad range of activities-from production of health commodities and human resources to generation of essential nonmedical services in support of health care, such as information services. However, to facilitate the analysis presented here we have opted to limit its scope to strict analysis of medical services or personal health services. Trade in these services, using the previously stated criteria for classifying trade in international services, takes four basic forms: export of health services, movement of users, movement of providers, and establishment of health care facilities abroad (12).

The term "export of health services" refers to movement of diagnostic information (such as laboratory test results or interpretation of a biopsy, electrocardiogram, X-ray, CAT scan, and so on) or therapeutic information (i.e., the treatment recommended following review of a patient's clinical record) between health professionals or institutions in different countries. As previously indicated, such export may take place electronically, by satellite, or by regular mail or transport. Except in certain border areas it is still rare. Its development requires an appropriate communications infrastructure shared by providers located in the various countries involved as well as standardized patterns of 
patient referral in order to ensure reliability of the information conveyed.

The international movement of health service consumers involves crossing at least one international border, passing from one country to another for the purpose of obtaining health services in the latter. In the United States balance of payments, the national accounts in the "service" category already consign the export of medical services, to what is defined as hospital income generated by foreign patients traveling to the country to receive some form of treatment (6). In 1991, income from this source totaled US\$ 672 million, an amount nearly double the US\$ 352 million recorded in 1981.

The international movement of health service providers likewise involves crossing at least one international border, passing from one country to another for the purpose of providing health services in the latter. This type of interaction affords an opportunity to improve access to health services that few in the area served are able to use for a variety of economic and cultural reasons, including lack of resources and unfamiliarity with the language employed. In addition, movement of providers tends to serve as a significant source for international transfer or exchange of clinical procedures and knowledge between physicians and hospitals. In order to maximize the effectiveness of this type of interaction, the criteria used to license and certify health service providers in the various countries involved need to be standardized.

The final form of trade, establishment of health care facilities abroad, is not common in North America but could offer considerable promise, given the few limitations on this type of foreign investment in the three countries of the region.

\section{NAFTA AND HEALTH SERVICES}

Before examining those aspects of NAFTA dealing with personal health services, it is necessary to mention certain matters relating to health services that were not included in the treaty (13). In the first place, the subjects of public health and social security services were not included in the treaty negotiations. This means, among other things, that the Canadian, U.S., and Mexican governments are free to retain or modify their own social security systems as they please (14).

Also excluded from the negotiations were health permits, including the various permits required by health authorities to establish private physicians' offices, clinics, laboratories, and hospitals. However, the three North American countries agreed to refrain from discriminating in favor of their own citizens with regard to issuance of such health permits.

The countries also agreed to continue applying their respective requirements with regard to licensing and certification of both general physicians and specialists. However, as noted below, NAFTA contains an annex that makes it possible to foresee a degree of subregional harmonization in the field of professional health care service provision.

The five NAFTA chapters that relate directly to the trading of health services (chapters XI, XII, XIV, XVI, and $X V I I)$ deal, respectively, with investments, cross-border services, financial services, temporary entry of business people, and intellectual property (12). The content of each chapter is examined below in describing the basic types of trade in health services.

The cross-border movement of services has long existed, as the transmission of diagnostic or therapeutic information by normal communications media has never been restricted. Indeed, for several years a number of private Mexican laboratories have regularly asked the United States for certain types of specialized laboratory examinations. In addition, Chapter XII of NAFTA specifically states that service providers in NAFTA countries will be free to choose the site where they will provide their services and that "A Party shall not require a service provider of another Party to establish or maintain a representative office, branch or any form of enterprise, or to be resident, in its territory as a condition for the cross-border provision of a service" (12).

Two factors constrain the unrestricted cross-border movement of consumers and their freedom to use health services in any part of North America. One is the lack of portability of many public and private health insurance plans. Canada's Health Act, for example, specifies that Canadian insurance companies will reimburse payments made for health services contracted outside the country only if they are for emergency services. In addition, the considerable restrictions applicable to physical migration between the United States and Mexico have intensified recently, thus limiting access by Mexican citizens to health services available on the U.S. side of the border. The most frequently cited example of this type of restriction is the recent approval in the State of California of Proposition 187, which prohibits use of public health and education services by undocumented immigrants (15).

Chapter XII of NAFTA contains an article and annex relating to the international mobility of health service providers. In accordance with the provisions of Article 1205, the three signatory countries assume responsibility for eliminating the permanent residence requirement as a condition for professional practice. This provision is particularly applicable in the case of Canada, where virtually all provinces require permanent residence as a condition for professional practice.

In addition, the provisions of Annex 1210.5 state that the governments will encourage professional groups and associations and other similar organizations in the three countries to meet and discuss, if they so desire, the criteria that might eventually be applied in the region with regard to the licensing and certification of professional health service providers. Such recommenda- 
tions as derive from these negotiations will be submitted to the three governments for a determination of their compatibility with NAFTA provisions. If the recommendations are indeed compatible, application will be made to the appropriate authorities for their immediate adoption. The only preceding negotiations of this type in North America are these begun in the early 1990s by United States and Canadian architects under the bilateral free trade agreement these two countries signed in 1991. In this case, notwithstanding significant progress achieved, the negotiations have yet to be finalized.

Chapter XVI of NAFTA, which deals with the temporary admission of business people, also contains provisions related to the cross-border mobility of health service providers. One of the purposes of this chapter is to facilitate both commercial transactions and exchanges of ideas, technology, and knowledge. To this end the chapter authorizes temporary entry of certain numbers and types of professionals, including physicians and their associates. This does not mean there is mutual recognition of licenses and certifications, as the activities covered are limited to teaching and research.

Foreign investment for the purpose of establishing health care facilities will be subject to the provisions of Chapter XI, which apply to any type of investment. The three countries agreed to refrain from reversing the previously existing freedom with regard to establishment of foreign hospitals and private clinics in their territory, although naturally the requirements applicable to the installation of these facilities (such as the certificate of need in Canada and the United States) will continue to remain in effect.

Two additional chapters deserving of special comment are Chapter XIV, which deals with financial services, and Chapter XVII, which covers intellectual property. The former contains an annex (VII) on insurance stipulating that access to the Mexican market by Canadian and U.S. insurance companies will be subject to three transi- tion periods running through the year 2000, after which all restrictions will be eliminated. It is quite possible, therefore, that North American health insurance companies will progressively increase their presence in the Mexican market, something that could possibly lead to an increase in the costs of care related to this type of financing.

Finally, Article 1709 of the NAFTA chapter dealing with intellectual property establishes the possibility that patents will not be granted for "diagnostic, therapeutic, and surgical methods for the treatment of humans and animals" (12). This exception to the granting of patents, which has been a part of Mexican law since 1991, will continue in effect under NAFTA.

\section{CONSEQUENCES OF LIBERALIZED TRADE FOR HEALTH SERVICES}

In view of the above considerations, what might the effects of NAFTA be on health services in Mexico? Such effects can be classified as either direct or indirect. Indirect effects are mediated by the general repercussions that NAFTA may eventually have on the economic and social development of Mexico. As conditions related to income, employment, and access to goods and services change, it might be expected that changes will also take place in epidemiologic profiles and that the demand for health services will increase. Both of these developments can be expected to have a profound effect on the configuration and operation of the National Health System. The long-term importance of these effects notwithstanding, however, their detailed analysis is beyond the scope of this study. Hence, this article describes only a few of the possible direct consequences of the treaty for the provision, regulation, and financing of medical services. For our purposes, it is useful to examine these consequences in terms of the possible risks to, and benefits for, the Mexican health care system $(14,16)$.
As regards benefits, NAFTA offers a potential for expansion of the market served by the medical-industrial complex in Mexico and promotion of foreign investment-thus creating employment, reducing foreign currency flight, increasing access to technology, and improving the competitive capacity, accessibility, quality, and productivity of services. This is already occurring in cities such as Aguascalientes, Mazatlán, and Tijuana, where hospitals financed partly or wholly by North American firms are about to open their doors. In fact, the intent of these firms is to extend their operations (in step with recovery of the Mexican economy) to almost all the roughly 20 Mexican cities with over 500000 inhabitants, where about $20 \%$ of the Mexican population with access to private health services resides $(14,16,17)$.

NAFTA also makes it possible to propose that Canadian and U.S. insurance companies pay for services provided in Mexico to U.S. and Canadian citizens by providers willing to be governed by international certification requirements. One particularly promising possibility is that Medicare might cover the medical expenses of the widespread community of retired U.S. citizens residing in Mexico, who in May 1988 totaled 396000 (over 15\% of the total number of retired U.S. residents in other countries) (18). Another potentially beneficial action would be to establish low-technology health care facilities (such as facilities for the chronically ill and nursing homes for the elderly) in Mexico for U.S. and Canadian patients, taking advantage of the relatively low costs of care in Mexico. Conversely, NAFTA affords national health service providers an opportunity to establish Mexican health care facilities in Canada and the United States to serve the considerable Hispanic populations there as well as temporary farm workers arriving from Mexico and other Latin American countries.

In addition, the free movement of service providers will make it possible 
to improve access to services that are hard to use for economic, cultural, or other reasons. Also, as previously indicated, the intensification of this provider movement can also increase exchanges of clinical knowledge and procedures between physicians and institutions in the three signatory nations $(14,16)$.

Risks posed by NAFTA include possible strengthening of the role played by curative medicine and so-called "defensive" medicine, accompanied by an increase in the costs of care and irrational use of technology. Another serious risk is that there will be uncontrolled expansion of inefficient tools for financing health care, particularly traditional insurance plans. Mexico, with its population of 92 million, represents one of the most promising insurance markets in Latin America. In 1992, total medical insurance sales exceeded US\$ 4 billion; but it is estimated that the potential market is 10 times larger. This is especially true in the area of accident and illness insurance, which in the first six months of 1994 recorded an increase of $21 \%$ over $1993(14,16,19,20)$.

Another possible risk is that there will be a lack of financing for private national institutions as a result of a decline in the demand for their services. This risk has led organizations of Mexican clinics and hospitals to propose formation of strategic alliances and to request government intervention to promote their capitalization.

Another risk of liberalized trade is that there will be less stimulus for national research and technologic development as a consequence of increased access to North American scientific centers. This possibility seems especially noteworthy when viewed within the context of the enormous asymmetry existing in this regard within the region: Whereas in Mexico US\$ 40 million is invested annually in the field of health research, each year the U.S. and Canadian governments alone invest US\$ 8 billion and Can\$ 200 million, respectively, in this area $(14,16,21)$.
Finally, it is worth drawing attention to a possible increase in the flight of skilled personnel from Mexico as a result of greater professional and economic incentives in Canada and the U.S. Such a flight has both advantages and disadvantages. Potential advantages include remittance of a portion of the income of these workers to Mexico. Disadvantages include flight of talent and the loss of benefits generated by funds invested in training individuals who subsequently decide to emigrate. For example, the 111 nurses who withdrew from public service in Jamaica in 1990 cost that country US\$ 1.7 million in training and education costs $(14,16,22)$.

\section{CONCLUSIONS}

In strictly commercial terms, the advantages held by Mexico vis-à-vis its North American partners are the low cost of health care within its borders and certain cultural and geographic factors that will enable Mexican providers to access the broad market offered by North American retirees residing in Mexico as well as the extensive Hispanic populations living in Canada and the United States. On the other hand, North American firms have in their favor increased access to capital, technology, administrative knowledge, marketing networks, and highly specialized professional medical services.

For Mexico to exploit its advantages and reduce the risks of liberalized trade, it will need to protect the considerable advances already made in regard to institutional consolidation, human resource training, extension of coverage, and identification and correction of weaknesses in its health system. In this regard, efforts to strengthen the system should be directed at more clearly defining the functions of health service regulation, financing, and provision-functions that should ideally be assigned to separate institutions so that performance of one function will not interfere with performance of the others and so that an appropriate system of checks and balances can be maintained.

Even without such fundamental change, short-term progress can be made. The highest priority in this regard is to strengthen the Ministry of Health's capacity to establish norms for operation of the system that will make it possible to ensure health service quality and in this way protect the health of the general public. To this end, explicit rules are required to govern establishment of health care facilities, standardization of criteria for licensing and certification of health professionals, and medical school certification. Relevant work in these areas has been done by the Mexican Commission for Hospital Certification, the Medical Specialties Certification Councils, and the Mexican Association of Faculties and Schools of Medicine, which are taking initial steps toward creating formal mechanisms for the certification and licensing of professionals, teaching centers, and health care facilities.

In view of the rapid appearance of new technologies and increasing contact with a highly technologydependent medical culture such as that existing in North America, it is also necessary to have flexible mechanisms and international cooperation networks available that will make it possible to evaluate not only the safety and efficacy of technologic innovations but also their cost-effectiveness.

In addition, given the importance of health to human well-being, there is a need to further strengthen the financial equity of the system. Canada has established a financial scheme worthy of study that has reconciled equity and universality with local government autonomy and freedom of choice for the consumer. A similar effort is also needed in seeking the optimum point at which the consumer is guaranteed certain minimal defense mechanisms, but without the excessive level of legal processes overwhelming the U.S. system. In general, all the regulatory effort should be aimed at achieving a 
certain equilibrium. The poor quality produced by an excessively lax regulatory framework brings with it costs for both the patient and society, but excessive regulation also generates unnecessary costs. The idea is to develop the minimal regulatory mechanisms needed to ensure quality of a homogeneous nature.

Overall, the new cross-border openness introduced into the medical ser- vices market will undoubtedly lead to a profound transformation of the Mexican health system. Hence, the principal recommendation at present should be to assume a "gradualistic" stancebecause time is required to orchestrate the reforms proposed in the preceding paragraphs, reforms that are essential for protecting not only Mexican institutions and companies but also the consumer.

\section{REFERENCES}

1. Samuelson P, Nordhaus W. Economics. 13th ed. New York: McGraw Hill; 1989.

2. Saborio $S$. The long and winding road from Anchorage to Patagonia. In: Saborio S, ed. The premise and the promise: free trade in the Americas. New Brunswick: Transaction Publishers; 1992:3-31.

3. Opalin L, Iturbide L. Importancia de los transportes en el desarrollo del comercio internacional. Comercio Internacional Banamex; 1991;3: 61-81.

4. Organization for Economic Cooperation and Development. Labour force statistics. Paris: OECD; 1993.

5. Instituto Nacional de Estadística, Geografía e Informática. XI Censo General de Población y Vivienda, 1990: perfil sociodemográfico. Aguascalientes, Mexico: INEGI; 1992.

6. Organization for Economic Cooperation and Development. Services: statistics on international transactions 1970-1991. Paris: OECD; 1992.

7. Centro de Estudios Estratégicos del Instituto Tecnológico y de Estudios Superiores de Monterrey. Entendiendo el TLC. México City: Fondo de Cultura Económica; 1994.

8. Editorial Plaza \& Janes. Diccionario de economía. Bogotá: Plaza \& Janes; 1984.
Acknowledgments. We are indebted to The Pew Charitable Trusts for the financial support needed to carry out the reviews and consultations on which this article is based, as well as the Mexican National Academy of Medicine and the National Council of Science and Technology for the ongoing support they provided.
9. McGraw-Hill Publishers. The McGraw-Hill dictionary of modern economics. 2nd ed. New York: McGraw-Hill; 1975.

10. Feketekuty G. El comercio internacional de servicios: panorama general y modelo para las negociaciones. Mexico City: Editorial Gernika; 1990.

11. United Nations Conference on Trade and Development. Trade in services: sectoral problems. New York: United Nations; 1991.

12. Secretaría de Comercio y Fomento Industrial. The North American Free Trade Agreement. Mexico City: Miguel Angel Porrúa; 1994.

13. Villareal-Gonda R. El ejercicio transfronterizo de la medicina. In: Mexico, Secretaría de Salud. El ejercicio transfronterizo del médico ante la apertura comercial. Mexico City: Secretaría de Salud; 1993:16-22.

14. Frenk J, Gómez-Dantés O, Cruz C, Chacón F, Hernández P. El TLC y los servicios médicos. 2nd ed. Mexico City: Academia Nacional de Medicina; 1994.

15. Cornelius WA. ¿Ninguna salida? La migración mexicana hacia los Estados Unidos y la relación bilateral después del TLC. Este país 1995;26-31.

16. Gómez-Dantés O, Frenk J, Cruz C. Consequences of the North American Free Trade Agreement for health services: a perspective from Mexico. Am J Public Health 1994; 1591-1597.

17. Carlino M. Outpatient care: US companies respond to Mexican demand for quality health care. El financiero internacional 1994;July 25-31:10-11.

18. Warner D, Reed K. Health care across the border: the experience of U.S. citizens in Mexico. Austin, Texas: Lyndon B. Johnson School of Public Affairs, The University of Texas at Austin; 1993.

19. Bamrud J. Insurance: NAFTA, the future of free trade in North America [special report]. U.S./Latin trade 1993;September:44A.

20. Delgadillo M. Suben los seguros $14 \%$ sus ventas. Reforma 1994;14 September:25A.

21. Commission on Health Research for Development. Health research: essential link for equity in development. Cambridge, MA: Oxford University Press; 1990.

22. World Bank. World development report 1993: investing in health. New York: Oxford University Press; 1993.

Manuscript received on 7 July 1995. Revised version accepted for publication on 20 December 1995.

RESUMEN El presente artículo discute el futuro del intercambio comercial de servicios personales de salud en América del Norte en el contexto del Tratado de Libre Comercio (TLC) y la posible influencia de este último sobre la atención de salud de la población mexicana. En la primera parte se definen conceptos relacionados con el intercambio internacional de servicios en general y de servicios de salud en particular y se analizan los componentes del TLC que afectan a la prestación, regulación y financiamiento de estos servicios, así como a su futuro intercambio en la zona del TLC. Al final del artículo se hacen recomendaciones dirigidas a ayudar al sistema nacional de salud de México a enfrentar los riesgos y aprovechar las oportunidades que brinda la incorpo-

El comercio de servicios de salud en América del Norte en el contexto del Tratado de Libre Comercio ración de la economía mexicana a un mercado más amplio. 